\title{
HUBUNGAN ANTARA INDEKS HARGA PENGGUNA (IHP) MENGIKUT WILAYAH DI MALAYSIA*
}

\author{
Zulkefly Abdul Karim \& Norain Mod Asri ${ }^{1}$ \\ M. Farid Wajdi ${ }^{2}$ \\ Antoni $^{3}$ \\ ${ }^{1}$ Fakultas Ekonomi dan Perniagaan Universiti Kebangsaan Malaysia \\ ${ }^{2}$ Fakultas Ekonomi Universitas Muhammadiyah Surakarta \\ E-mail: faridwazdi2000@yahoo.com \\ ${ }^{3}$ Fakultas Ekonomi Bung Hatta Padang
}

\begin{abstract}
Di Malaysia, isu serakan dalam perletakan harga boleh diteliti antara wilayah Malaysia Barat (Semenanjung Malaysia) dengan Malaysia Timur (Sabah dan Sarawak). Dari segi sejarah, kedua-dua wilayah tersebut memang terpisah dari segi politik dan ekonomi sehingga tertubuhnya Malaysia pada tahun 1963. Justeru, kajian ini bertujuan untuk memeriksa hubungan antara Indeks Harga Pengguna (IHP) di Semenanjung Malaysia dengan Sabah dan Sarawak. Di samping itu, kajian ini juga bertujuan untuk menentukan Indeks Harga Pengguna (IHP) di wilayah manakah yang menjadi peneraju atau pengikut. Jangka masa kajian bermula dari bulan Januari tahun 1970 hingga bulan Mac tahun 2005 yang melibatkan cerapan sebanyak 423 bulan. Kaedah ekonometrik siri masa telah diaplikasikan dalam kajian ini.

Dapatan kajian menunjukkan kewujudan hubungan jangka panjang (kointegrasi) antara Indeks Harga Pengguna (IHP) mengikut wilayah di Malaysia. Dalam jangka panjang, didapati IHP di Malaysia Timur (Sabah dan Sarawak) merupakan indeks harga peneraju, manakala IHP di Semenanjung Malaysia adalah indeks harga pengikut. Walau bagaimanapun, dalam jangka pendek didapati kewujudan hubungan sebab-menyebab dua hala di kalangan IHP mengikut wilayah (kecuali bagi kes Sabah dan Sarawak). Keputusan ujian penguraian varians pula menjelaskan bahawa IHP di Semenanjung Malaysia memberikan pengaruh yang besar dalam menerangkan variasi perubahan terhadap IHP di Sabah dan Sarawak. Hasil kajian ini telah memberikan beberapa implikasi kepada dasar kawalan harga yang perlu dilakukan oleh pihak kerajaan untuk mengawal kestabilan harga.
\end{abstract}

Kata kunci: indeks harga pengguna, kointegrasi, vektor koreksi kesalahan, fungsi tindak balas, penguraian varian

\footnotetext{
" Artikel ini merupakan bagian dari hasil penelitian yang bertajuk "Variabiliti Harga Relatif dan Inflasi di Malaysia" yang dibiayai oleh Fakulti Ekonomi dan Perniagaan, UKM Malaysia
} 


\section{PENGENALAN}

Kestabilan paras harga atau inflasi merupakan pra syarat kepada pertumbuhan kegiatan ekonomi dalam jangka panjang. Justeru, sasaran paras harga telah menjadi semakin popular di kalangan Bank Pusat sebagai sasaran matlamat akhir dalam melaksanakan dasar kewangan. Misalnya, sasaran kadar inflasi telah dijadikan sebagai matlamat akhir dasar kewangan di kebanyakan negara seperti di Australia, Kanada, New Zealand, Sweden, United Kingdom, Korea dan Chile. Begitu juga di Malaysia, walaupun strategi dasar kewangan telah beralih daripada sasaran agregat kewangan kepada sasaran kadar bunga mulai pertengahan tahun 1995 hingga kini, namun sasaran kadar inflasi sebagai matlamat akhir ekonomi masih lagi dikekalkan. Kadar inflasi yang stabil menjadi petanda yang baik kepada persekitaran kegiatan ekonomi yang lebih kondusif daripada pelbagai aspek seperti agihan sumber yang efisien, mengukuhkan lagi sentimen pelaburan dan penggunaan, menyediakan insentif untuk menabung, mengukuhkan kebajikan ekonomi dan melancarkan perjalanan program pembangunan negara.

Di Malaysia, isu serakan dalam perletakan harga boleh diteliti antara wilayah Malaysia Barat (Semenanjung Malaysia) dan Malaysia Timur (Sabah dan Sarawak). Dari segi sejarah, kedua-dua wilayah memang terpisah dari segi politik dan ekonomi sehingga tertubuhnya Malaysia pada tahun 1963. Usaha mengintegrasikan ekonomi wilayah-wilayah ini berhadapan dengan beberapa masalah, antaranya jarak fizikal serta wilayah-wilayah ini sudah pun mempunyai perdagangan tradisi masingmasing. Walaupun begitu, kemajuan dalam teknologi pengangkutan dan perhubungan serta perlaksanaan dasar yang sesuai memungkinkan wilayah-wilayah ini berintegrasi sebagai sebuah pasaran sepunya (common market). Justeru, maklumat mengenai hubungan jangka panjang atau kointegrasi antara indeks harga mengikut di wilayah tersebut amatlah perlu untuk memberi gambaran tentang sejauh mana usaha mengintegrasi ekonomi Malaysia Barat dan Malaysia Timur berupaya mencapai sasarannya.

Perbezaan wilayah antara Semenanjung Malaysia, Sabah dan Sarawak telah menyebabkan berlakunya serakan harga atau perbezaan Indeks Harga Pengguna di wilayah-wilayah terbabit. Justeru, perbezaan Indeks Harga Pengguna tersebut sudah pasti menyukarkan pihak kerajaan khususnya Bank Negara Malaysia dan Kementerian Perdagangan Dalam Negeri dan Hal Ehwal Pengguna untuk mengawal kestabilan paras harga. Perbezaan paras harga antara wilayah di Malaysia tersebut telah memberikan beberapa persoalan penting. Pertama, adakah IHP di ketiga-tiga wilayah tersebut berkointegrasi yaitu mempunyai hubungan dalam jangka panjang. Jika IHP di wilayahwilayah tersebut berkointegrasi, ini menunjukkan pergerakan harga di ketiga-tiga wilayah mempunyai arah pergerakan yang sama dalam jangka panjang dan ini sudah pasti menyukarkan usaha mengawal harga. Kedua, persoalan indeks harga di wilayah manakah yang menjadi peneraju (leader) dan yang mana pula menjadi pengikut (follower) juga perlu diberi perhatian oleh penggubal dasar. Hal ini penting diselidiki untuk melihat indeks harga di wilayah mana yang paling dominan dan seterusnya memudahkan strategi kawalan harga oleh pihak berwajib. 
Ketiga, adakah indeks harga di ketiga-tiga wilayah tersebut saling berhubungan antara satu sama lain sama ada dalam jangka pendek atau jangka panjang. Umumnya, kita boleh membuat hipotesis awal bahawa IHP di Semenanjung Malaysia adalah paling dominan kerana wilayah tersebut yang secara ekstensif berdagang dengan Sabah dan Sarawak. Maka, dalam hal ini adalah dijangkakan IHP di Semenanjung Malaysia adalah indeks harga peneraju, manakala IHP di Sabah dan Sarawak adalah indeks harga pengikut. Tambahan lagi, kos pengangkutan yang tinggi terpaksa ditanggung oleh sektor pemborong dan peruncit di Sabah dan Sarawak, dan situasi ini menyebabkan mereka terpaksa menjual barangan dan perkhidmatan pada harga yang lebih tinggi berbanding dengan pemborong dan peruncit di wilayah Semenanjung Malaysia. Sama ada kenyataan tersebut benar ataupun tidak, ianya merupakan persoalan empirikal yang menarik untuk diselidiki. Justeru, objektif utama kajian ini adalah untuk menyiasat sama ada IHP di Semenanjung Malaysia, Sabah dan Sawarak mempunyai hubungan jangka panjang (berkointegrasi), di samping mengenalpasti indeks harga peneraju dan pengikut di Malaysia. Untuk memudahkan perbincangan, kajian ini dibahagikan kepada beberapa bahagian. Bahagian kedua, membicarakan latar belakang kajian lepas, manakala bahagian ketiga menyentuh daripada aspek metodologi kajian. Bahagian keempat pula membentangkan keputusan empirikal, manakala bahagian kelima meringkas dan merumuskan penemuan kajian.

\section{KAJIAN LEPAS}

Kajian mengenai hubungan antara Indeks Harga Pengguna (IHP) mengikut wilayah di kebanyakan negara maju maju lebih menekankan daripada aspek hubungan antara kadar inflasi dengan variabiliti harga relatif. Dari segi teori, inflasi boleh mempengaruhi variabiliti harga menerusi perkaitannya dengan kos meletak harga. Kos perletakan harga lebih kerap dirujuk sebagai kos menu (menu cost) yang meliputi pelbagai jenis kos seperti kos pentadbiran, kos mengekalkan kesetiaan produk dan sebagainya yang dihadapi firma semasa menaikkan atau menurunkan harga. Kos menu boleh meningkat atau merosot dengan meningkatnya kadar inflasi. Model kos menu Fielding dan Mizen (2000) menunjukkan bahawa inflasi boleh meningkatkan sebaran harga dan seterusnya variabiliti harga sekiranya kenaikan kadar inflasi membawa kepada peningkatan dalam kos menu. Sebaliknya, variabiliti harga berkurang jika kenaikan kadar inflasi mengurangkan kos menu. Model kos menu Caballero dan Engle (1993) juga memberikan ramalan yang hampir sama.

Hubungan antara inflasi dengan variabiliti harga boleh juga dijelaskan secara alternatif berdasarkan maklumat tak sempurna (lihat misalnya Lucas, 1973) atau kewujudan kos carian (lihat misalnya Benabou, 1988). Implikasi daripada modelmodel ini menunjukkan bahawa faktor-faktor yang berkaitan dengan perletakan harga boleh mempengaruhi hubungan positif atau negatif antara inflasi dengan variabiliti harga. Justeru, bentuk sebenar hubungan antara dua pemboleh ubah ini hanya dapat ditentukan secara empiris. Kajian Okun (1971) adalah yang terawal membincangkan secara empiris 
isu hubungan antara inflasi dengan variabiliti inflasi. Data yang digunakan adalah data inflasi bagi negara-negara OECD untuk tempoh 1951-1968. Dengan menganalisis hubungan antara min dengan sisihan piawai inflasi, beliau mendapati hubungan antara dua pemboleh ubah tersebut adalah positif.

Lach dan Tsiddon (1992) juga mendapati hubungan positif antara inflasi dengan variabiliti harga relatif. Dalam kajian ini, variabiliti harga relatif diukur menggunakan purata berwajaran perbezaan pertama logaritma harga bagi kumpulan barang dalam indeks harga pengguna. Dalam kajian Parsley (1996) dan Dabelle dan Lamont (1997), variabiliti harga relatif diukur menggunakan sisihan piawai perbezaan logaritma harga daripada minnya. Keputusan regresi bagi seluruh bandar dan kumpulan produk di Amerika Syarikat mendapati wujud hubungan jangka pendek positif antara variabiliti harga relatif dengan inflasi. Namun mereka tidak menemui wujudnya hubungan jangka panjang antara dua pemboleh ubah ini. Fielding dan Mizen (2000) juga menggunakan ukuran variabiliti harga relatif yang serupa seperti Dabella dan Lamont (1997). Kajian mereka terhadap negara-negara Kesatuan Eropah mendapati bahawa apabila arah aliran berketentuan (deterministic trend) diabaikan, hubungan antara unsur stokastik variabiliti sentiasa positif. Kajian ini juga mendapati bahawa unsur stokastik variabiliti harga relatif dengan kadar inflasi tidaklah berkelangsungan dan akan terhapus dalam tempoh yang singkat. Terdapat juga kajian yang menemui hubungan negatif antara variabiliti harga relatif dengan inflasi (lihat misalnya, Reinsdorf (1994)).
Di samping itu, terdapat juga beberapa kajian yang melihat hubungan antara indeks harga domestik yaitu Indeks Harga Pengeluar (PPI) dengan Indeks Harga Pengguna (IHP) di negara maju ataupun di negara sedang membangun. Misalnya, kajian Shrestha (1986) di negara Amerika Syarikat telah melihat hubungan antara Indeks Harga Pengguna (IHP) dengan Indeks Harga Pengeluar (PPI) berdasarkan model kebolehjadian maksimum (maximum likelihood). Kajian tersebut telah melihat pengaruh empat komponen PPI terhadap IHP yang terdiri daripada PPI untuk kos pembinaan, PPI untuk peralatan modal, PPI barangan pengguna tahan lama dan PPI terhadap barangan pengguna tidak tahan lama. Hasil kajian mendapati hubungan lat antara PPI dengan IHP adalah stabil. Secara umumnya, didapati peningkatan PPI signifikan menyebabkan peningkatan IHP. Di samping itu, juga didapati pengaruh PPI barangan pengguna tahan lama tidak signifikan mempengaruhi IHP, sebaliknya perubahan IHP sangat sensitif dipengaruhi oleh perubahan PPI barangan pengguna tidak tahan lama. Keputusan kajian ini menjelaskan bahawa PPI adalah indeks peneraju, manakala IHP adalah indeks harga pengikut.

Di samping itu, Akdi, Berument dan Cilasun (2006) telah mengkaji hubungan antara perbezaan indeks harga di Turki. Kajian tersebut telah cuba mengenalpasti kewujudan hubungan jangka panjang antara Indeks Harga Pengguna (IHP) dengan Indeks Harga Borong (WPI). Jangka masa kajian bermula dari bulan Januari tahun 1987 hingga bulan Ogos tahun 2004. Dapatan kajian menunjukkan bahawa kedua-dua indeks harga yaitu IHP dan WPI adalah 
berintegrasi pada I(1). Keputusan ujian kointegrasi Johansen pula menunjukkan dapatan yang tidak konsisten atau tidak selaras. Ini disebabkan dengan menggunakan kriteria statistik trace didapati wujud hubungan jangka panjang antara IHP dengan WPI (satu vektor berkointegrasi), sebaliknya dengan menggunakan kriteria statistik max tidak wujud hubungan jangka panjang antara kedua-dua indeks harga tersebut. Sebaliknya, kedua-dua nilai statistik tersebut adalah bererti atau signifikan apabila wujudnya dua persamaan vektor yang berkointegrasi dalam sistem persamaan. Setelah mengambilkira elemen bermusim, didapati wujud dua persamaan vektor yang berkointegrasi antara IHP dan WPI. Walau bagaimanapun, analisis dengan menggunakan kaedah periodogram pula mendapati kedua-dua indeks tersebut adalah tidak mempunyai hubungan jangka panjang. Justeru, analisis hanya boleh dibuat dalam jangka pendek sahaja. Berdasarkan hasil kajian didapati kedua-dua indeks harga tersebut saling mempengaruhi antara satu sama lain dalam jangka pendek..

Di samping itu, terdapat juga beberapa penelitian yang mengkaji pengaruh harga antarbangsa terhadap harga domestik. Misalnya, penelitian Baffes dan Gardner (2003) telah mendapati perubahan harga komoditi antarbangsa telah memberikan kesan kepada perubahan harga domestik di negara Chili, Mexico dan Argentina. Begitu juga dengan penelitian Mundlak dan Larson (1992), dalam penelitian mereka terhadap 58 buah negara di dunia mendapati variasi perubahan harga dunia telah tersebar serta memberikan pengaruh yang dominan terhadap perubahan harga domestik. Sebaliknya, Quiroz dan Soto (1993) dengan menggunakan sampel 60 buah negara, merumuskan bahwa pengaruh harga komoditi antarbangsa memberikan kesan yang marjinal atau tidak wujud terhadap perubahan harga domestik. Sebaliknya, Morriset (1998) telah memeriksa jurang antara harga dunia dengan harga komoditi domestik di beberapa negara industri utama sepanjang tahun 1975 hingga tahun 1994. Hasil penelitian menunjukkan bahwa peningkatan harga dunia cenderung menyebabkan peningkatan harga domestik, sebaliknya jatuhnya harga dunia tidak pula mempengaruhi harga domestik. Selain itu, penelitian Aw, Batra dan Roberts (2001) dengan menggunakan data peringkat firma telah mendapati adanya perbedaan harga yang sistematik antara harga ekspor dengan harga domestik terhadap pengeluaran barangan elektronik di negara Taiwan. Kebanyakan firma dalam sektor industri tersebut melakukan diskriminasi harga yaitu mengenakan harga yang tinggi di pasaran domestik, sebaliknya mengenakan harga yang rendah di pasar ekspor.

Di Malaysia, kebanyakan kajian mengenai inflasi lebih bertumpu kepada faktorfaktor yang mempengaruhi inflasi dengan menggunakan pendekatan teori inflasi sebelah permintaan dan sebelah penawaran. Misalnya, lihat kajian Chye dan Semudram (1988) dan Mohd. Azlan Shah (1998). Walau bagaimanapun, kajian terkini oleh Mohd. Azlan Shah, Mansor dan Zulkefly (2005) telah melihat perspektif yang berbeza yaitu hubungan antara kadar inflasi dengan variabiliti harga relatif mengikut wilayah di Malaysia. Hasil kajian tersebut mendapati kadar inflasi signifikan dan berhubungan positif mempengaruhi variabiliti harga relatif mengikut wilayah di Malaysia. Walau bagaimanapun, kajian tersebut tidak dapat 
menjelaskan dua persoalan penting yaitu kewujudan hubungan jangka panjang antara indeks harga mengikut wilayah dan indeks harga di wilayah manakah yang menjadi peneraju atau pengikut. Di samping itu, Mohd Azlan Shah, Zulkefly \& Zurina (2005) juga mendapati bahawa Indeks Harga Pengeluar (PPI) dan Indeks Harga Pengguna (IHP) tidak mempunyai hubungan jangka panjang, tetapi dalam jangka pendek didapati PPI merupakan indeks harga peneraju, manakala IHP adalah indeks harga pengikut. Justeru, kajian ini akan cuba mengisi ketandusan kajian mengenai hubungan antara IHP mengikut wilayah dengan melihat hubungan jangka panjang (kointegrasi) dan hubungan arah sebab-menyebab antara IHP mengikut wilayah di Malaysia. Setakat pengetahuan penyelidik, belum lagi ada kajian yang dilakukan untuk melihat hubungan antara perbezaan indeks harga mengikut wilayah tersebut. Hal ini telah memberikan motivasi kepada kajian ini untuk menerokai persoalan tersebut dengan lebih mendalam.

\section{DATA DAN METODE KAJIAN}

Bahagian ini membincangkan data dan metode kajian yang digunakan untuk menganalisis hubungan yang wujud antara Indeks Harga Pengguna (IHP) mengikut wilayah di Malaysia. Data IHP mengikut wilayah merangkumi tempoh masa bulanan yang bermula dari bulan Januari 1970 hingga April 2005 diperolehi dari Jabatan Perangkaan Malaysia. Data IHP tersebut adalah indeks IHP purata mengikut sembilan kumpulan barang yang digunakan untuk membentuk IHP bagi setiap wilayah.
Dalam menganalisis hubungan yang wujud antara pemboleh ubah-pemboleh ubah tersebut, beberapa ujian statistik perlu dijalankan supaya penganggaran yang dibuat tidak menyalahi hukum ekonometrik. Pertama, ujian punca unit dilakukan bagi melihat tahap kepegunan pemboleh ubah siri masa sama ada pegun dalam bentuk paras atau pun pegun dalam bentuk pembezaan. Kedua, ujian kointegrasi pula dijalankan bagi melihat kemungkinan wujud hubungan jangka panjang antara pemboleh ubah IHP mengikut wilayah di Malaysia. Jika hubungan jangka panjang wujud, maka ujian model vektor pembetulan ralat (vector error correction model atau VECM) pula akan dilakukan. Ujian ini berupaya menerangkan pelarasan jangka pendek akibat daripada kejutan ke atas keseimbangan jangka panjang. Ia juga mampu melihat arah hubungan sebab-menyebab antara pemboleh ubah bebas dengan bersandar sama ada bersifat jangka panjang atau jangka pendek.

Sebaliknya, jika hubungan jangka panjang tidak wujud atau tiada kointegrasi, maka hukum ekonometrik menjelaskan bahawa hubungan antara pemboleh ubahpemboleh ubah tersebut boleh dijelaskan melalui penganggaran dalam bentuk pembezaan, misalnya pembezaan pertama. Untuk itu, satu model vektor autoregresif (VAR) dalam bentuk pembezaan akan dilakukan. Model ini akan dapat menjelaskan hubungan sebab-menyebab jangka pendek yang wujud antara pemboleh ubah yang dikaji.

Seterusnya, kaedah ujian fungsi tindak balas dan penguraian varians pula digunakan untuk melihat tindak balas dinamik di kalangan pemboleh ubah IHP mengikut wilayah tersebut. 
Bahagian seterusnya membincangkan secara lebih mendalam setiap ujian yang telah dijalankan.

\section{Ujian Punca Unit}

Ujian punca unit dilakukan untuk melihat tahap kepegunan setiap pemboleh ubah. Sesuatu pemboleh ubah dikatakan pegun jika min dan variannya adalah konstan melalui masa. Ia boleh menjadi pegun sama ada dalam peringkat tingkat (level), atau pun pembezaan (difference). Setiap pemboleh ubah dalam persamaan regresi perlu pegun pada tahap yang sama, yaitu sama ada semua pemboleh ubah pegun dalam bentuk tingkat atau semua pemboleh ubah pegun dalam bentuk pembezaan, misalnya pembezaan pertama. Syarat ini perlu dipenuhi agar anggaran yang didapati sah digunakan. Jika tidak, anggaran regresi palsu akan wujud, yaitu keputusan anggaran didapati sangat baik tetapi hubungan sebenarnya tidak wujud. Granger dan Newbold (1974) menyatakan bahawa keadaan ini boleh dikenal pasti apabila nilai $\mathrm{R}^{2}$ lebih besar daripada nilai statistik $\mathrm{DW}$. $^{1}$

Dalam kajian ini, ujian punca unit kaedah Dickey-Fuller (DF) atau Imbuhan (Augmented) Dickey-Fuller (ADF) dan Phillips-Perrons telah diaplikasikan. ${ }^{2}$

\section{Uji Kointegrasi}

Langkah seterusnya selepas melakukan ujian kepegunan ialah melihat hubungan antara pemboleh ubah-pemboleh ubah tersebut

DW ialah statistik Durbin-Watson untuk melihat kewujudan masalah autokorelasi.

2 Penerangan lanjut mengenai ujian punca unit Dickey Fuller, Augmented Dickey Fuller dan ujian Phillips Perrons tidak dilakukan kerana kesemuanya telah dianggap sebagai ujian yang standard dalam analisis data siri masa. melalui ujian kointegrasi. Hanya siri masa yang mempunyai darjah integrasi yang sama sahaja akan dipertimbangkan untuk ujian kointegrasi ini. Gonzalo (1994) berpendapat bahawa ujian kointegrasi Johansen yang diperkenalkan oleh Johansen (1988) dan Johansen dan Juselius (1990), adalah kaedah yang terbaik berbanding dengan kaedahkaedah yang lain. Keputusan yang diperolehi daripada kaedah Johansen ini mengambil kira sifat-sifat penting siri masa bagi datadata yang terlibat. Kaedah ini juga memberikan penganggaran untuk semua vektor kointegrasi yang wujud dalam sesuatu sistem siri masa dan statistik ujian yang sesuai. Di samping itu, kaedah Johansen juga membolehkan satu ujian hipotesis dapat dilakukan ke atas koefisien dalam vektor kointegrasi. Kaedah ini berdasarkan kepada penganggaran kebolehjadian maksimum (maximum likelihood estimation) yang menguji kewujudan vektor kointegrasi di kalangan siri masa. Johansen (1988) mengenal pasti model lat tertabur bagi vektor pemboleh ubah $\mathrm{Y}$ ialah seperti berikut;

$Y_{t}=\Pi_{1} Y_{t-1}+\Pi_{2} Y_{t-2}+\ldots+\Pi_{k} Y_{t-k}+\varepsilon_{t}$

$\mathrm{t}=1,2, \ldots, \mathrm{n}$

yang mana $Y_{t}$ ialah $\mathrm{Nxl}$ vektor bagi pemboleh ubah stokastik (IHP SEM $_{\text {, IHP }}$ SAB dan $\left.\mathrm{IHP}_{\mathrm{SWK}}\right) ; \Pi_{1}, \Pi_{2}, \ldots, \Pi_{k}$ ialah $\mathrm{n} \times \mathrm{n}$ parameter yang tidak diketahui dan $\varepsilon_{\mathbf{t}}$ ialah vektor ralat Gaussian dengan andaian min sifar dan varian konstan. Jika $Y_{t}$ tidak pegun, sistem persamaan [1] di atas boleh ditulis semula dalam bentuk pembezaan pertama dan bentuk terturun seperti berikut; 


$$
\begin{aligned}
\Delta Y_{t}= & \Gamma_{1} \Delta Y_{t-1}+\Gamma_{2} \Delta Y_{t-2}+\ldots+ \\
& \Gamma_{k-1} \Delta Y_{t-k+1}+\Pi Y_{t-k}+e_{t}
\end{aligned}
$$

dengan

$\Gamma_{i}=-\left[I-\Pi_{1}-\Pi_{2}-\ldots-\Pi_{i}\right]$,

$\mathrm{i}=1,2, \ldots, \mathrm{k}-1$

dan

$\Pi=-\left[I-\Pi_{1}-\Pi_{2}-\ldots-\Pi_{k}\right]$

Persamaan [2] di atas adalah dalam bentuk model tradisi VAR (vector autoregression) dengan perbezaan pertama kecuali bahagian $\Pi Y_{t-k}$. Matrik $\Pi$ dikenali sebagai matrik kesan jangka panjang (long-run impact matrix). Matrik ini akan menentukan sama ada kointegrasi wujud dalam sistem persamaan ataupun sebaliknya. Darjah kointegrasi ini akan ditentukan oleh pangkat matrik $\Pi$ ini. Sekiranya pangkat bagi matrik $\Pi$ ialah $r$ maka wujud sebanyak $r$ kointegrasi di kalangan siri masa dalam $Y_{t}$ dan matrik $\Pi$ akan diwakili oleh $a^{\prime}$, yang mana matrik a mewakili koefisien pelarasan yaitu mengukur kekuatan hubungan kointegrasi yang wujud, manakala matrik b mewakili parameter yang terdapat dalam vektor kointegrasi. Jika $r$ sama dengan sifar, bermakna tidak wujud hubungan jangka panjang di kalangan siri masa tersebut. Dalam kes $0<$ pangkat $(\Pi)=r<p$, yang mana $r$ ialah pangkat matrik dan $\mathrm{p}$ ialah bilangan pemboleh ubah dalam sistem, wujud satu atau lebih hubungan di kalangan pemboleh ubah ini. Prosedur Johansen ini akan menentukan pangkat bagi matrik $\Pi$ dengan menguji sama ada eigenvalues matrix $\Pi$, yaitu anggaran bagi matrik $\Pi$, berbeza daripada sifar ataupun sebaliknya. Sekiranya pangkat matrik $\Pi$ adalah sifar, matrik $\Pi$ ini adalah matrik nol.

Dengan menggunakan eigenvalues yang dimaksudkan ini, Johansen dan Juselius (1990) membuktikan bahawa hipotesis mengenai kewujudan selebih-lebih $r$ vektor kointegrasi boleh diuji dengan menggunakan dua statistik ujian kebolehjadian seperti berikut;

$$
\begin{aligned}
& \lambda_{\text {trace }}(r)=-T \sum_{i=r+1}^{n} \ln \left(1-\hat{\lambda}_{i}\right) \\
& \lambda_{\max }(r, r+1)=-T \ln \left(1-\hat{\lambda}_{r+1}\right)
\end{aligned}
$$

yang mana $\mathrm{T}$ ialah jumlah cerapan yang digunakan dan $\hat{\lambda}$ ialah nilai eigenvalues yang diperolehi daripada matrik $\Pi$. Statistik ujian yang pertama akan menguji hipotesis nol yang menyatakan bahawa bilangan kointegrasi kurang daripada $r$ melawan hipotesis alternatif bilangan kointegrasi sama atau lebih besar dengan $r+1$. Manakala, statistik ujian yang kedua pula akan digunakan untuk menguji hipotesis nol yang sama tetapi hipotesis alternatifnya ialah bilangan kointegrasi sama dengan $r+1$ sahaja. Nilai kedua-dua statistik ujian ini kemudiannya akan dibandingkan dengan nilai kritikal yang boleh didapati daripada Osterwald-Lenum (1992). Sekiranya nilai statistik ujian lebih besar daripada nilai kritikal ini pada aras keertian tertentu, maka hipotesis nol akan ditolak dan hipotesis alternatif akan diterima.

\section{Model Vektor Pembetulan Ralat (VECM)}

Model vektor pembetulan ralat dilakukan bagi mengekang gelagat jangka panjang pemboleh ubah endogen supaya menumpu kepada hubungan kointegrasinya sementara 
memberi ruang kepada pelarasan dinamik jangka pendek. Dengan perkataan lain, model ini dilakukan untuk melihat berapa lama kejutan yang berlaku dapat diperbetulkan sehingga mencapai keseimbangan menerusi pelarasan jangka pendek.

Pada asasnya model VEC adalah model VAR yang mengandungi terma faktor ralat yang diambil daripada persamaan kointegrasi. Ia dapat dibentuk seperti berikut:

$$
\begin{aligned}
& \Delta \mathrm{IHP}_{\mathrm{SAB}, \mathrm{t}}=\alpha_{10}+\lambda_{\mathrm{SAB}} \hat{\varepsilon}_{\mathrm{t}-1}+\sum_{\mathrm{i}=1}^{\mathrm{n}} \delta_{1 \mathrm{i}} \Delta \mathrm{IHP}_{\mathrm{SAB}_{\mathrm{t}-\mathrm{i}}}+ \\
& \sum_{\mathrm{i}=1}^{\mathrm{n}} \phi_{\mathrm{li}} \Delta \mathrm{IHH}_{\mathrm{SEM}_{\mathrm{t}-\mathrm{i}}}+\sum_{\mathrm{i}=1}^{\mathrm{n}} \gamma_{\mathrm{li}} \Delta \mathrm{IHH} \mathrm{SWK}_{\mathrm{t}-\mathrm{i}}+\mathrm{v}_{\mathrm{lt}} \\
& \Delta \mathrm{IHP}_{\mathrm{SEM}_{\mathrm{t}}}=\alpha_{20}+\lambda_{\mathrm{SEM}} \hat{\varepsilon}_{\mathrm{t}-1}+\sum_{\mathrm{i}=1}^{\mathrm{n}} \delta_{2 \mathrm{i}} \mathrm{AIHP}_{\mathrm{SAB}_{\mathrm{t}-\mathrm{i}}}+ \\
& \sum_{\mathrm{i}=1}^{\mathrm{n}} \phi_{2 \mathrm{i}} \Delta \mathrm{IHP}_{\mathrm{SEM}, \mathrm{t}-\mathrm{i}}+\sum_{\mathrm{i}=1}^{\mathrm{n}} \gamma_{2 \mathrm{i}} \Delta \mathrm{IHP}_{\mathrm{SWK}_{\mathrm{t}-\mathrm{i}}}+\mathrm{v}_{2 \mathrm{t}}
\end{aligned}
$$

$$
\begin{array}{r}
\Delta \mathrm{IHP}_{\mathrm{SWK}_{\mathrm{t}}}=\alpha_{30}+\lambda_{\mathrm{SWK}_{\mathrm{t}-1}}+\sum_{\mathrm{i}=1}^{\mathrm{n}} \delta_{3 \mathrm{i}} \Delta \mathrm{IHP}_{\mathrm{SAB}_{\mathrm{t}-\mathrm{i}}}+ \\
\sum_{\mathrm{i}=1}^{\mathrm{n}} \phi_{3 \mathrm{i}} \Delta \mathrm{IHP}_{\mathrm{SEM}_{\mathrm{t}-\mathrm{i}}}+\sum_{\mathrm{i}=1}^{\mathrm{n}} \gamma_{3 \mathrm{i}} \Delta \mathrm{IHP}_{\mathrm{SWK}_{\mathrm{t}-\mathrm{i}}}+\mathrm{v}_{3 \mathrm{t}}
\end{array}
$$

yang mana $\Delta$ menunjukkan simbol perbezaan dan $\hat{\varepsilon}_{t-1}$ adalah faktor ralat daripada persamaan kointegrasi. Koefisien $\lambda$ pula mengukur tempoh pelarasan ke arah keseimbangan apabila berlaku sesuatu kejutan. Jika $\lambda$ signifikan, ia juga menunjukkan hubungan sebab menyebab jangka panjang daripada pemboleh ubah bebas kepada pemboleh ubah bersandar. Sementara itu, setiap koefisien $\delta, \phi$ dan $\gamma$ pula mengukur hubungan arah sebabmenyebab jangka pendek daripada pemboleh ubah bebas kepada pemboleh ubah bersandar.

Jika tiada hubungan jangka panjang yang wujud antara pemboleh ubah, maka ujian penyebab Granger akan dilakukan untuk melihat hubungan jangka pendek yang mungkin terbentuk. Ujian ini serupa dengan ujian VECM dalam persamaan [5a-5c], melainkan faktor ralat $\left(\widehat{\varepsilon}_{\mathrm{t}-1}\right)$ kini ditiadakan. Ia hanya dapat melihat hubungan jangka pendek yang wujud antara pemboleh ubahpemboleh ubah yang dikaji.

\section{Penguraian Varian dan Fungsi Tindak Balas}

Untuk melihat darjah kekuatan hubungan antara pemboleh ubah IHP mengikut wilayah di Malaysia, analisis penguraian varian dan fungsi tindak balas dijalankan ke atas model VECM. Analisis penguraian varian dapat menentukan peratusan variasi dalam satu pemboleh ubah yang disebabkan oleh pemboleh ubah-pemboleh ubah lain yang terdapat dalam sistem. Ini bermakna kaedah ini dapat memberikan maklumat mengenai kepentingan sesuatu pemboleh ubah kepada pemboleh ubah lain yang terdapat dalam sistem. Kaedah penghuraian varian boleh dijelaskan dengan merujuk kepada model vektor autoregresif (VAR) seperti berikut:

$Y_{t}=A_{0}+A_{1} Y_{t-1}+e_{t}$

dimana $Y_{t}$ ialah vektor pemboleh ubah endogenous dan $Y_{t-1}$ ialah vektor pemboleh ubah exogenous. A ialah matrik koefisien yang perlu dianggarkan dan $e_{t}$ ialah vektor ralat. Dengan merujuk kepada persamaan [6], nilai peramalan untuk tempoh $\mathrm{n}$ bagi 
pelbagai nilai $Y_{t+i}$ dengan bersyaratkan nilai $Y_{t}$, boleh ditulis seperti berikut:

$$
E_{l} Y_{t+1}=\left(I+A_{1}+A_{1}^{2}+\ldots+A_{1}^{n-1}\right) A_{0}+A_{1}^{n} Y_{t}
$$

dengan andaian nilai koefisien $A_{0}$ dan $A_{1}$ adalah diketahui. Manakala ralat peramalan yang terlibat ialah:

$$
e_{t+n}+A_{1} e_{t+n-1}+A_{1}^{2} e_{t+n-2}+\ldots++A_{1}^{n-1} e_{t+1}
$$

Bagi model VAR klasik ini, ralat peramalan e, boleh diterjemahkan ke dalam bentuk kejutan $\varepsilon_{1 \mathrm{t}}, \varepsilon_{2 \mathrm{t}}, \ldots, \varepsilon_{\mathrm{nt}}$. Oleh yang demikian, kaedah penguraian varian ini dapat menunjukkan peratusan variasi dalam sesuatu pemboleh ubah yang disebabkan oleh pemboleh ubah itu sendiri dan pemboleh ubah lain yang terdapat dalam sistem. Sekiranya kejutan $\varepsilon_{1 \mathrm{t}}$ tidak memberi kesan kepada variasi dalam $Y_{2 \mathfrak{t}}$, untuk semua tempoh masa yang terlibat, maka $\mathrm{Y}_{2 \mathrm{t}}$ dianggap sebagai exogenous dalam sistem tersebut.

Fungsi tindak balas pula akan dapat menterjemahkan tindak balas dinamik sesuatu pemboleh ubah ke atas kejutan atau inovasi yang berlaku dalam pemboleh ubah yang lain termasuk pemboleh ubah itu sendiri. Secara teorinya, fungsi tindak balas boleh dijelaskan dengan merujuk kepada model VAR dalam persamaan [6]. Vektor $e_{t}$ adalah merupakan vektor inovasi yaitu perubahan dalam $e_{1}$ akan memberi kesan kepada $Y_{1}$. Selain itu perubahan dalam $e_{1}$ juga akan memberi kesan kepada nilai hadapan pemboleh ubah yang terdapat dalam vektor $Y_{t}$ melalui struktur dinamik yang terdapat dalam sistem tersebut. Oleh yang demikian, fungsi tindak balas merupakan satu proses untuk mengesan tindak balas dinamik sesuatu pemboleh ubah ke atas satu unit kejutan atau inovasi yang berlaku dalam pemboleh ubah lain termasuk pemboleh ubah itu sendiri. Dari segi ekonometrik, fungsi tindak balas diperolehi dengan menggunakan persamaan berikut:

$$
Y_{t}=\beta_{t}+\sum \phi_{i} e_{t-i}
$$

yang mana $\beta_{t}$ ialah pintasan dan $\phi_{i}$ ialah matrik $\mathrm{n} \times \mathrm{n}$ dengan unsur $\phi_{i j}(i)$ mengukur impak satu unit perubahan dalam sebutan ralat terhadap pemboleh ubah endogenous yang terdapat dalam sistem tersebut. Manakala $\mathrm{e}_{\mathrm{t}-\mathrm{a}}$ adalah vektor $\mathrm{n} \times 1$.

\section{KEPUTUSAN KAJIAN}

Sebelum membentangkan keputusan empirikal, eloklah terlebih dahulu dibincangkan arah aliran IHP mengikut wilayah dan analisis statistik deskriptif. Ini dapat memberikan gambaran awal mengenai hubungan yang wujud di kalangan indeks harga tersebut. Rajah 1 menunjukkan IHP di ketiga-tiga wilayah di Malaysia mempunyai arah aliran yang sama dan semakin meningkat. Hal ini seolah-olah memberikan gambaran awal bahawa IHP di ketiga-tiga wilayah tersebut mempunyai hubungan jangka panjang. Sama ada kenyataan ini benar ataupun tidak ianya perlulah diuji dengan menggunakan kaedah ujian kointegrasi Johansen (1988). Secara lebih spesifik, didapati dari awal tahun 1970 hingga akhir tahun 1997, didapati IHP Sabah mencatatkan angka tertinggi diikuti dengan IHP Sarawak dan IHP Semenanjung. 


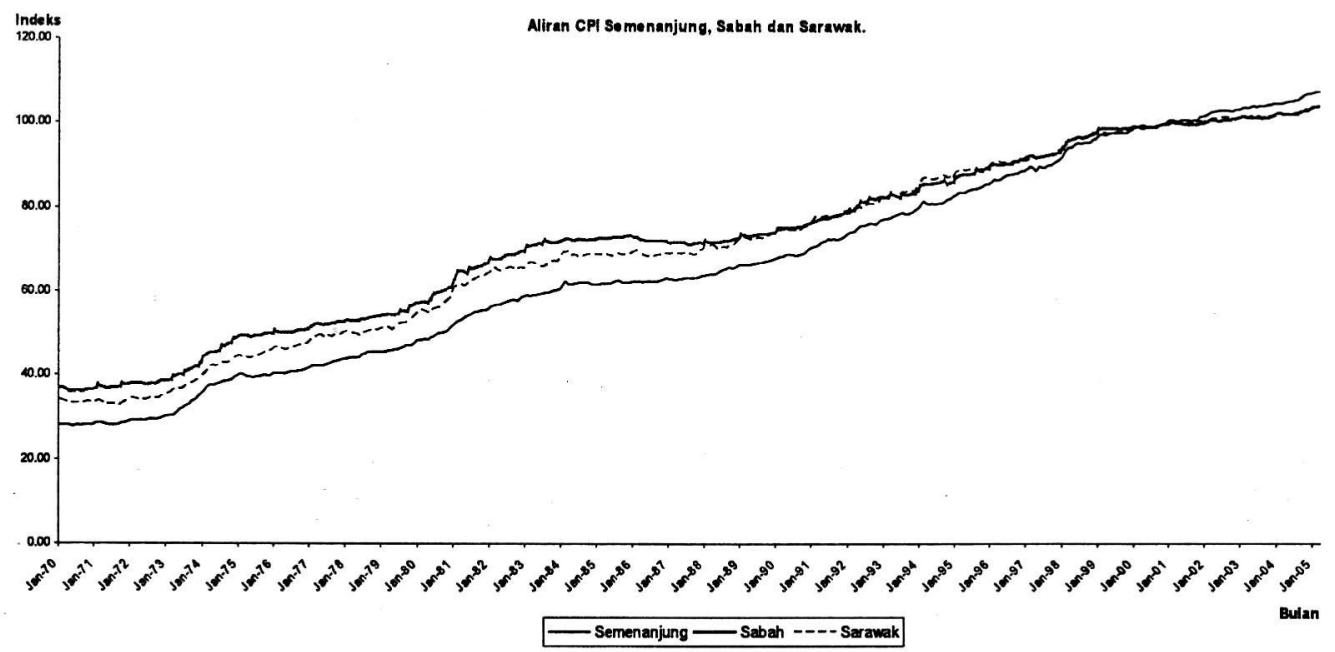

Rajah 1. Perkembangan Indeks Harga Pengguna di Semenanjung, Sabah dan Sarawak

Sebaliknya, sejak dari awal tahun 1998, IHP Semenanjung dilihat semakin meningkat dan mencatatkan angka tertinggi diikuti dengan IHP Sabah dan IHP Sarawak. Sebagai contohnya, IHP di Semenanjung Malaysia secara relatifnya telah meningkat dengan pesat mulai krisis kewangan pada 1997, berbanding dengan IHP di Sabah dan Sarawak. Senario ini juga dapat ditunjukkan pada Jadual 1, yang mana IHP di Semenanjung telah mencatatkan nilai tertinggi yaitu 108.30 pada bulan Mac 2005 .

Jadual 1. Keputusan Analisis Deskriptif

\begin{tabular}{lrrr}
\hline \multicolumn{1}{c}{$\begin{array}{c}\text { Statistik } \\
\text { Deskriptif }\end{array}$} & Semenanjung & Sabah & Sarawak \\
\hline Min & 66.91031 & 72.98173 & 71.17787 \\
Median & 63.68000 & 72.98000 & 69.83000 \\
Maksimum & 108.3000 & 105.0000 & 104.8000 \\
Minimum & 27.90000 & 36.10000 & 32.82000 \\
Sisihan piawai & 24.20980 & 20.65298 & 22.14324 \\
Kepencongan & 0.081752 & -0.187522 & -0.160764 \\
Kurtosis & 1.858324 & 1.930526 & 1.851480 \\
Jarque-Bera & 23.44403 & 22.63813 & 25.07116 \\
Kebarangkalian & 0.000008 & 0.000012 & 0.000004 \\
\hline
\end{tabular}

Secara umumnya, peningkatan IHP di ketigatiga wilayah tersebut mencerminkan berlakunya peningkatan kos sara hidup, di samping mengurangkan kuasa beli pengguna.

Walaupun ketiga-tiga IHP tersebut seolah-olah dilihat mempunyai hubungan dalam jangka panjang, namun ianya perlu diperhalusi lagi menerusi analisis statistik. Di samping itu, kita juga perlu mengungkaikan persoalan yang berkaitan dengan IHP di wilayah manakah yang menjadi peneraju (leader) dan pengikut (follower). Bagi tujuan tersebut, maka terlebih dahulu ujian kepegunan data dilakukan bagi menentukan tahap kepegunan setiap pemboleh ubah untuk mengelakkan masalah regresi palsu. Jadual 2 secara keseluruhannya menunjukkan bahawa nilai mutlak statistik ujian ADF dan PP pada peringkat paras adalah lebih kecil daripada nilai mutlak kritikal untuk ketigatiga IHP mengikut wilayah tersebut. Ini bererti, semua pemboleh ubah IHP, tidak pegun pada peringkat paras. Namun, pada peringkat pembezaan pertama pula, didapati 
Jadual 2. Keputusan Uji Unit root Kaedah ADF dan PP

\begin{tabular}{lcc}
\hline \multicolumn{1}{c}{ Variabel } & $\begin{array}{c}\text { Augmented } \\
\text { Dickey Fuller (ADF) }\end{array}$ & $\begin{array}{c}\text { Phillip } \\
\text { Perron (PP) }\end{array}$ \\
\hline Paras & & \\
IHP & & \\
Semenanjung & 0.386491 & 0.406241 \\
IHP Sarawak & -0.896608 & -0.853656 \\
IHP Sabah & -1.095956 & -0.925987 \\
& & \\
Pembedaan Pertama & & \\
IHP & & \\
Semenanjung & $-17.04541^{*}$ & $-17.14314^{*}$ \\
IHP Sarawak & $-12.05219^{*}$ & $-17.48005^{*}$ \\
IHP Sabah & $-12.11871^{*}$ & $-17.99338^{*}$ \\
\hline
\end{tabular}

Nota: Model ini dijana dengan pintasan dan satu lat.

* Signifikan pada tingkat signifikansi $1 \%$.

nilai mutlak statistik ujian $\mathrm{ADF}$ dan $\mathrm{PP}$ adalah lebih besar daripada nilai mutlak kritikal pada aras keertian 1 peratus. Oleh yang demikian, hipotesis nol ditolak yang menggambarkan ketiga-tiga pemboleh ubah IHP tersebut adalah pegun dan berintegrasi pada peringkat pembezaan pertama yaitu I(1). Kepegunan ketiga-tiga pemboleh ubah IHP pada peringkat pembezaan pertama atau I(1), membolehkan ujian kointegrasi Johansen dijalankan untuk menentukan sama ada wujud atau pun tidak hubungan jangka panjang di kalangan pembolehubah IHP di Semenanjung, Sarawak dan Sabah. Keputusan ujian kointegrasi Johansen ditunjukkan pada Jadual 3.

Berdasarkan kepada Jadual 3, jelas menunjukkan kewujudan hubungan jangka panjang di antara ketiga-tiga IHP di Semenanjung, Sarawak dan Sabah. Ini terbukti apabila terdapat sekurang-kurangnya satu vektor yang berkointegrasi pada aras keertian 5 peratus. Ini ditunjukkan oleh nilai statistik kebolehjadian yang lebih besar berbanding dengan nilai kritikal pada aras keertian 5 peratus. Namun, ujian kointegrasi tidak mampu mengenalpasti arah hubungan
Jadual 3. Keputusan Uji Kointegrasi Johansen di antara IHP di Semenanjung, Sarawak dan Sabah

\begin{tabular}{cccc}
\hline $\begin{array}{c}\text { Angka } \\
\text { Persamaan } \\
\text { Kointegrasi }\end{array}$ & $\begin{array}{c}\text { Nilai } \\
\text { Eigen }\end{array}$ & $\begin{array}{c}\text { Statistik } \\
\text { Kebolehjadian }\end{array}$ & $\begin{array}{c}0.05 \\
\text { Nilai } \\
\text { Kritikal }\end{array}$ \\
\hline $\mathrm{r}=0^{*}$ & 0.103445 & 61.27519 & 35.19275 \\
$\mathrm{r}=1$ & 0.022522 & 15.74073 & 20.26184 \\
$\mathrm{r}=2$ & 0.014857 & 6.241767 & 9.164546 \\
\hline
\end{tabular}

Nota: Uji ini dijana dengan pintasan (tanpa tren) dalam persamaan kointegrasi dan lima lat.

* Signifikan pada tingkat signifikansi $5 \%$

tersebut. Justeru, ujian sebab-menyebab Granger versi Model Vektor Pembetulan Ralat akan diaplikasi bagi mengenalpasti arah hubungan di antara ketiga-tiga IHP tersebut.

\section{Ujian Model Vektor Pembetulan Ralat (VECM)}

Jadual 4 menunjukkan keputusan ujian VECM terhadap indeks harga di ketiga-tiga wilayah di Malaysia. Berdasarkan kajian, didapati perubahan IHP di Sabah dan perubahan IHP di Sarawak signifikan menjadi penyebab kepada perubahan IHP di Semenanjung Malaysia dalam jangka panjang. Ini dibuktikan apabila nilai statistik t pemboleh ubah bebas $\hat{\varepsilon}_{t-1}$ terhadap pemboleh ubah bersandar $\triangle \mathrm{IHP}_{\text {SEM }}$ (signifikan paras keertian 5\%). Selain itu, dalam jangka pendek juga menunjukkan bahawa perubahan IHP di Sabah dan perubahan IHP di Sarawak juga signifikan menjadi penyebab kepada perubahan IHP di Semenanjung Malaysia. Sebaliknya, tiada pengaruh pemboleh ubah bebas dalam jangka panjang terhadap perubahan IHP di Sabah dan perubahan IHP Sarawak. Sebaliknya, dalam jangka pendek didapati perubahan IHP di 
Jadual 4. Ujian Penyebab Granger Versi VECM

\begin{tabular}{|c|c|c|c|c|}
\hline \multirow{3}{*}{$\begin{array}{l}\text { Variabel } \\
\text { Bersandar }\end{array}$} & \multicolumn{4}{|c|}{ Model Multivariat } \\
\hline & Ujian $t$ & & Ujian $F$ & \\
\hline & $\hat{\varepsilon}_{t-1}$ & $\triangle \mathrm{H} \mathrm{HP}_{\mathrm{SAB}}$ & $\Delta \mathrm{H} \mathrm{P}_{\text {SEM }}$ & $\Delta \mathrm{H} P_{\text {swk }}$ \\
\hline$\triangle \mathrm{HHP}$ SAB & $\begin{array}{c}-0.00715 \\
(-0.61493)\end{array}$ & - & $\begin{array}{c}3.35218 \\
(0.0056)^{*}\end{array}$ & $\begin{array}{c}2.13356 \\
(0.0607)^{*}\end{array}$ \\
\hline$\triangle \mathrm{HHP}$ SEM & $\begin{array}{c}-0.00357 \\
(-2.43735)^{* *}\end{array}$ & $\begin{array}{c}3.20957 \\
(0.00746)^{m+m}\end{array}$ & $\cdot$ & $\begin{array}{c}1.988995 \\
(0.079299)^{\circ}\end{array}$ \\
\hline$\Delta \mathrm{HP} P_{\text {swk }}$ & $\begin{array}{l}-0.018741 \\
-1.296203\end{array}$ & $\begin{array}{c}0.685473 \\
(0.634684)\end{array}$ & $\begin{array}{c}4.548070 \\
(0.000480)^{m}\end{array}$ & - \\
\hline
\end{tabular}

Nota: * signifikan pada aras keertian $10 \%$

*t signifikan pada aras keertian $5 \%$

*** signifikan pada aras keertian $1 \%$

Semenanjung Malaysia signifikan mempengaruhi perubahan IHP di Sabah dan Sarawak. Begitu juga sebaliknya, perubahan IHP di Sabah dan perubahan IHP di Sarawak juga signifikan mempengaruhi perubahan IHP di Semenanjung Malaysia. Ini menunjukkan kewujudan hubungan sebabmenyebab dua hala yang bersifat jangka pendek antara perubahan IHP di Semenanjung Malaysia dengan perubahan IHP di Sarawak dan Sabah. Selain itu, juga didapati hubungan sebab-menyebab sehala daripada perubahan IHP di Sarawak terhadap perubahan IHP di Sabah.

\section{Keputusan Ujian Fungsi Tindak Balas dan Penguraian Varians}

Keputusan daripada ujian fungsi tindak balas pada Rajah 2 menunjukkan IHP di Semenanjung mempengaruhi perubahan IHP di Sarawak sekitar $0.17 \%$ hingga $0.34 \%$, sedangkan IHP Sarawak hanya mempengaruhi $0.05 \%$ hingga $0.3 \%$ perubahan dalam IHP Semenanjung. Pada masa yang sama, IHP Sabah pula hanya menyebabkan IHP Semenanjung berubah sekitar $0.05 \%$ hingga $0.22 \%$, manakala IHP Semenanjung pula mempengaruhi perubahan IHP Sabah dalam lingkungan $0.15 \%$ hingga $0.34 \%$. Justeru, secara keseluruhannya, IHP Semenanjung sebenarnya lebih dominan mempengaruhi variasi perubahan IHP di Sarawak dan Sabah. Selain itu, IHP Sabah pula menyebabkan IHP Sarawak berubah sebanyak $0.05 \%$ hingga $0.07 \%$, tetapi IHP di Sarawak lebih dominan mempengaruhi variasi perubahan IHP di Sabah yaitu sekitar $0.12 \%$ hingga $0.33 \%$.

Seterusnya, keputusan yang diperolehi daripada ujian penguraian varian seperti yang tertera pada Jadual 5 turut mengesahkan dapatan daripada ujian fungsi tindak balas sebelum ini. Secara spesifik, IHP Sarawak berupaya menerangkan variasi perubahan IHP Semenanjung daripada $16.9 \%$ pada tempoh ke-50 bulan dan meningkat kepada $33.2 \%$ pada tempoh ke- 423 bulan. Manakala, IHP Sabah hanya menerangkan $1.9 \%$ variasi perubahan dalam IHP Semenanjung dalam tempoh ke-50 bulan dan meningkat kepada $14.4 \%$ pada tempoh ke-423 bulan. Ini secara tidak langsung, menjelaskan bahawa IHP Sarawak lebih kuat berbanding dengan IHP Sabah dalam menerangkan variasi perubahan IHP Semenanjung. Sebaliknya, IHP Semenanjung berupaya menerangkan variasi 


\section{Response to Cholesky One S.D. Innovations}

Response of SEMENANJUNG to SEMENANJUNG

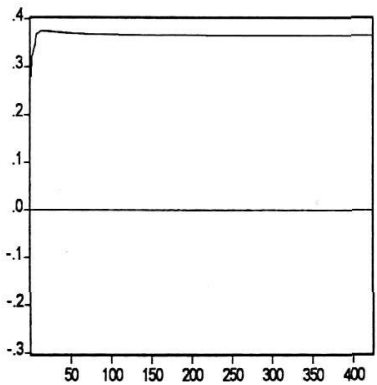

Response of SARAWAK to SEMENANJUNG

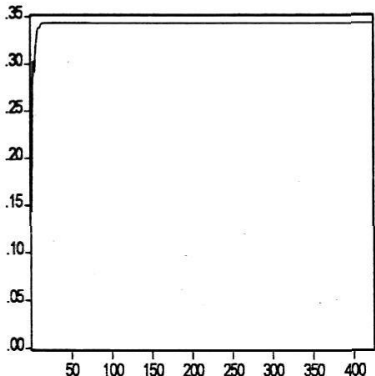

Response of SABAH to SEMENANJUNG

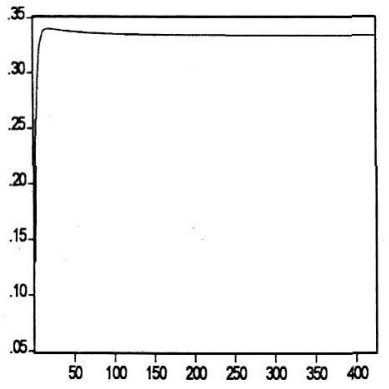

Response of SEMENANJUNG to SARAWAK

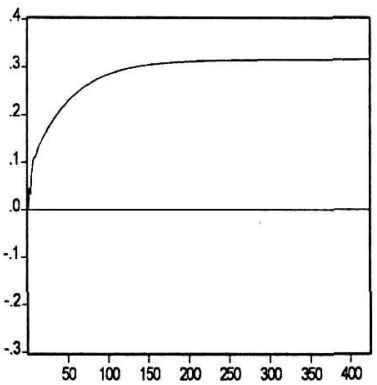

Response of SEMENANJUNG to SABAH

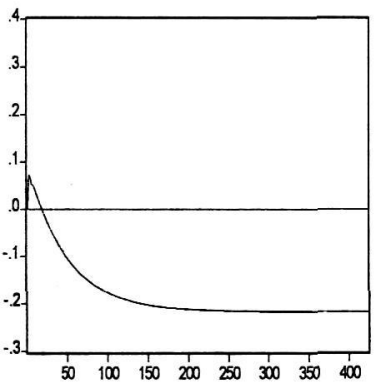

Response of SARAWAK to SABAH
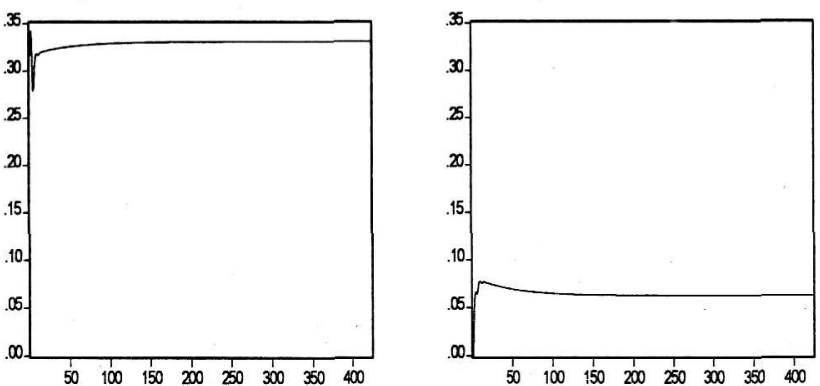

Response of SABAH to SARAWAK

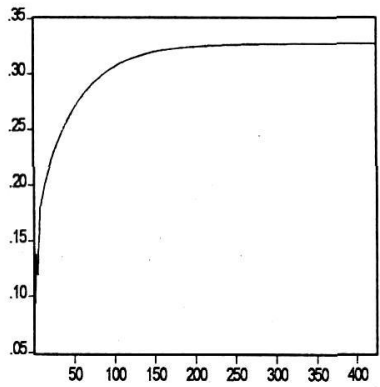

Response of SABAH to SABAH

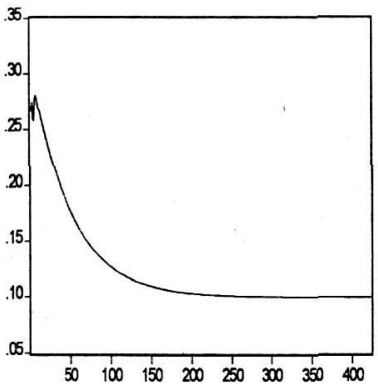

Rajah 2. Keputusan Uji Fungsi Tindak Balas di antara IHP Semenanjung, Sarawak dan Sabah

perubahan IHP Sarawak sebanyak $17 \%$ dan meningkat kepada $51 \%$ dari tempoh pertama hingga tempoh ke-423 bulan. Di sini, dapat diperhatikan bahawa semenjak tempoh ke50, pengaruh IHP Semenanjung terhadap IHP Sarawak semakin penting berbanding dengan pengaruh IHP Sarawak sendiri.
Walau bagaimanapun, pengaruh IHP Sabah terhadap IHP Sarawak tidak dominan yaitu semakin berkurangan daripada $2.3 \%$ dalam tempoh ke-50 bulan kepada $1.8 \%$ dalam tempoh ke-423 bulan. Bagi kes IHP Sabah pula, didapati IHP Semenanjung berupaya menerangkan sebanyak $17 \%$ hingga $51 \%$ 
Tabel 5. Keputusan Ujian Penguraian Varians di antara IHP Semenanjung, Sarawak dan Sabah

Panel A

\begin{tabular}{ccccc}
\hline \multicolumn{5}{c}{ Penguraian Varians bagi IHP Semenanjung: } \\
\hline Tempoh & Sisihan piawai & IHP Semenanjung & IHP Sarawak & IHP Sabah \\
\hline 1 & 0.280197 & 100.0000 & 0.000000 & 0.000000 \\
50 & 2.884241 & 81.06524 & 16.97519 & 1.959577 \\
100 & 4.431439 & 68.98991 & 24.64576 & 6.364327 \\
150 & 5.709248 & 62.22190 & 28.30605 & 9.472045 \\
200 & 6.799008 & 58.38619 & 30.25981 & 11.35400 \\
250 & 7.753023 & 56.04658 & 31.42234 & 12.53108 \\
300 & 8.607189 & 54.51317 & 32.17632 & 13.31051 \\
350 & 9.385678 & 53.44516 & 32.69914 & 13.85570 \\
400 & 10.10495 & 52.66372 & 33.08097 & 14.25531 \\
423 & 10.41923 & 52.37119 & 33.22381 & 14.40500 \\
\hline
\end{tabular}

Panel B

\begin{tabular}{ccccc}
\hline \multicolumn{5}{c}{ Penguraian Varians bagi IHP Sarawak: } \\
\hline Tempoh & Sisihan piawai & IHP Semenanjung & IHP Sarawak & IHP Sabah \\
\hline 1 & 0.347117 & 17.07394 & 82.92606 & 0.000000 \\
50 & 3.312781 & 51.04048 & 46.64740 & 2.312120 \\
100 & 4.738846 & 51.18178 & 46.69121 & 2.127018 \\
150 & 5.829753 & 51.14451 & 46.84484 & 2.010642 \\
200 & 6.747783 & 51.10366 & 46.95773 & 1.938609 \\
250 & 7.555484 & 51.07290 & 47.03550 & 1.891601 \\
300 & 8.284945 & 51.05057 & 47.09023 & 1.859198 \\
350 & 8.955227 & 51.03409 & 47.13014 & 1.835761 \\
$\mathbf{4 0 0}$ & 9.578734 & 51.02158 & 47.16031 & 1.818110 \\
$\mathbf{4 2 3}$ & 9.852308 & 51.01680 & 47.17181 & 1.811387 \\
\hline \multicolumn{5}{c}{} \\
\hline \multicolumn{5}{c}{ Penguraian Varians bagi IHP Sabah: } \\
\hline Tempoh & Sisihan piawai & IHP Semenanjung & IHP Sarawak & \\
\hline 1 & 0.312655 & 17.29121 & IHP Sabah \\
50 & 3.248085 & 51.06105 & 23.132277 & 73.57651 \\
100 & 4.641368 & 51.25694 & 31.30480 & 25.23089 \\
150 & 5.725454 & 50.80270 & 35.65767 & 17.43826 \\
200 & 6.644294 & 50.39955 & 38.28070 & 11.53963 \\
250 & 7.454058 & 50.10593 & 39.96772 & 9.926346 \\
300 & 8.185233 & 49.89552 & 41.12022 & 8.984260 \\
350 & 8.856629 & 49.74126 & 41.94898 & 8.309756 \\
400 & 9.480725 & 49.62465 & 42.57057 & 7.804777 \\
$\mathbf{4 2 3}$ & 9.754427 & 49.58022 & 42.80679 & 7.612989 \\
\hline \multicolumn{5}{c}{}
\end{tabular}

variasi perubahan IHP di Sabah, manakala IHP Sarawak pula berupaya menerangkan sebanyak $9.13 \%$ pada tempoh pertama dan meningkat kepada $42.8 \%$ pada tempoh ke423 bulan. Satu perkara yang menarik berkaitan IHP Sabah ialah ia lebih kuat dipengaruhi oleh IHP Semenanjung dan IHP Sarawak berbanding dengan IHP Sabah sendiri. Secara keseluruhannya, keputusan ujian penguraian varian ini selari dengan dapatan daripada ujian fungsi tindak balas yang mana IHP Semenanjung lebih dominan mempengaruhi perubahan IHP Sarawak dan Sabah, serta IHP Sarawak pula lebih dominan mempengaruhi variasi dalam IHP Sabah. 


\section{RUMUSAN DAN IMPLIKASI}

Tujuan utama penelitian ini adalah untuk mengkaji hubungan antara indeks harga pengguna (IHP) mengikut wilayah di Malaysia yang terdiri dari Semenanjung Malaysia, Sabah dan Sarawak. Berdasarkan hasil penelitian, didapati indeks harga di tiga wilayah tersebut berkointegrasi yaitu mempunyai hubungan dalam jangka panjang. Di samping itu, keputusan uji VECM telah mendapati dalam jangka panjang perubahan indeks harga di Semenanjung Malaysia dipengaruhi oleh perubahan indeks harga di Sabah dan Sarawak. Ini menunjukkan dalam jangka panjang, Sabah dan Sarawak adalah indeks harga leader, sedangkan Semenanjung Malaysia memiliki indeks harga follower. Sebaliknya, dalam jangka pendek didapati, adanya hubungan dua hala di kalangan indeks harga tersebut, kecuali tiada pengaruh perubahan IHP di Sabah terhadap perubahan IHP di Sarawak. Hasil uji penguraian varians dan fungsi tindak balas juga menunjukkan IHP di Semenanjung lebih dominan dalam menerangkan variasi perubahan IHP di Sabah dan Sarawak.

Hasil penelitian ini memberikan beberapa implikasi pada dasar pengendalian harga pihak kerajaan. Pertama, oleh sebab adanya hubungan jangka panjang di kalangan indeks harga pengguna tersebut, maka kestabilan paras harga adalah sukar dikendalikan oleh pihak kerajaan khususnya Bank Negara Malaysia (BNM). Situasi ini memberikan gambaran bahwa dalam jangka panjang daya beli sektor rumah tangga sudah pasti tertekan. Tambahan lagi, menurut penelitian Mohd. Azlan Shah, Zulkefly dan Zurina (2005) perubahan IHP juga dipengaruhi oleh perubahan PPI (Indeks Harga Pengeluar). Ini berarti sebarang kenaikan PPI, cenderung menyebabkan sektor firma memindahkan beban tersebut kepada konsumen dalam bentuk kenaikan harga barang. Maka, dalam hal ini matlamat kestabilan harga sukar dicapai dengan menggunakan instrumen dasar keuangan. Dasar pengendalian harga secara langsung diperlukan untuk menjaga kestabilan harga. Kedua, keputusan penguraian varian dan fungsi tindak balas juga secara jelas menunjukkan bahwa indeks harga di Semenanjung Malaysia paling dominan mempengaruhi perubahan indeks harga di Sabah dan Sarawak. Dengan demikian usaha menstabilkan harga melalui pengendalian harga dalam jangka pendek di Semenanjung sangat diperlukan sebab pengaruhnya adalah sangat dominan dalam mempengaruhi tingkat harga di Sabah dan Sarawak. Ketiga, perbedaan harga relatif di tiga wilayah tersebut juga perlu dipantau dari waktu ke ke waktu agar tidak menekan daya beli konsumen khususnya di kalangan berpendapatan rendah.

Penelitian ini tidak melihat hubungan indeks harga mengikut kategori barang di wilayah-wilayah yang diteliti. Justeru dicadangkan, penelitian lebih lanjut perlu dilakukan pada kategori barang uintuk mendapatkan hasil penelitian yang lebih tepat. Hal ini penting bagi pihak kerajaan untuk mendapatkan informasi mengenai IHP mengikut kategori barang yang mana saja yang paling dominan dalam mempengaruhi harga barang- barang lain. Informasi tersebut adalah penting supaya langkah-langkah pengendalian harga yang pragmatik dapat diambil oleh pihak kerajaan. 


\section{RUJUKAN}

Akdi, Y., Berument, H. \& Cilasun, S.M. 2006. The Relationship between Different Price Indices: Evidence from Turkey. Physica A 360: 483-492.

Aw, B.Y., Batra, G. \& Roberts, M.J. 2001. Firm Heterogeneity and ExportDomestic Price Differentials: A Study of Taiwanese Electronics Products. Journal of International Economics, 54: 149-169.

Baffes, J \& Gardner, B. 2003. The Transmission of World Commodity Prices to Domestic Markets under Policy Reforms in Developing Countries. Policy Reform, vol. 6(3): 159-180.

Benabou, R. 1988. Search, Price Setting and Inflation. Review of Economic Studies 55: 353-76

Cabalerro, R. and Engle, E. 1993. Microeconomic Rigidities and Aggregate Price Dynamics. European Economic Review 37: 697-711.

Chye, Tan Eu dan M. Semudram. 1988. The Monetarist versus Neo-Keynesian Controversy over Inflation: the Malaysian Evidence. The Indian Economic Journal 36: 48-54.

Debelle, G and Lamont, O. 1997. Relative Price Variability and Inflation: Evidence from US Cities. Journal of Political Economy 105:132-52.

Fielding, David and Paul Mizen. 2000. Relative Price Variability and Inflation in Europe. Economica 67 (265), 57-78.

Gonzalo, J. (1994). Five Alternative Methods of Estimating Long-Run Equilibrium Relationships. Journal of Econometrics 60: 203-233.
Granger, C.W.J. and Newbold, P. (1974). Spurious Regressions in Econometrics, Journal of Econometrics, 2, 111-120.

Johansen, S. \& Juselius, K. (1990). Maximum Likelihood Estimation and Inferences on Cointegration with Application to the Demand for Money. Oxford Bulletin of Economics and Statistics, 52, 169-210.

Johansen, S. (1988). Statistical analysis of Cointegration Vectors. Journal of Economic Dynamic Control, 12, 231-254.

Lach, S and Tsiddon, D. 1992. The Behavior of Price and Inflation: an Empirical Analysis of Disaggregated Price Data. Journal of Political Economy 100:34989.

Lucas, JRE, (1973), "Some International Evidence on Output-Inflation Trade off", American Economic Review, 63, pp. 326- 334.

Mohd Azlan Shah Zaidi. 1998. Inflasi: Pengaruh Faktor Luaran dan Kesan Asimetrik. Tesis Sarjana Ekonomi. Universiti Kebangsaan Malaysia.

Mohd. Azlan Shah Zaidi, Mansor Jusoh \& Zulkefly Abdul Karim. 2005. Hubungan Variabiliti Harga Relatif dan Inflasi antara Wilayah Malaysia. Media Ekonomi, Vol. (11): 45-57.

Mohd. Azlan Shah Zaidi, Zulkefly Abdul Karim \& Zurina Kefeli@Zulkefli. 2005. Hubungan antara Indeks Harga Pengguna (CPI) dengan Indeks Harga Pengeluar (PPI): Bukti Empirikal di Malaysia. Dalam Prosiding Seminar Kebangsaan MACFEA ke-10: Ke Arah Pengguna dan Pengeluar yang 
Bertanggungjawab: 201-208 (cakera padat)

Morisset, J. 1998. Unfair trade? The Increasing Gap between World and Domestic Prices in Commodity Markets during the Past 25 years. The World Bank Economic Review, 12: 503-526.

Mundlak, Y. and Larson, D.F. 1992. On the Transmission of the World Agriculture Prices. The World Bank Economic Review, 6: 399-422.

Osterwald-Lenum, M. (1992). A Note with Quintiles of the Asymptotic Distribution of the Maximum Likelihood Cointegration Rank Test Statistics. Oxford Bulletin of Economics and Statistics 54: 461-471.

Parsley, David C, 1996. Inflation and Relative Price Variability in the Short and
Long Run: New Evidence from the United States. Journal of Money, Credit and Banking 28(3): 323-341.

Quiroz, J and Soto, R. 1993. International Price Signals in Agricultural Markets: do Government Care? Mimeo, the World Bank, October.

Reinsdorf, Marshall. 1994. "Price Dispersion, Seller Substitution and the U.S. CPI." BLS Working Paper 252.

Rotemberg, J. 1982. Monopolistic Price Adjustment and Aggregate Output. Review of Economics Studies 49: 517 531.

Shrestha, K. 1986. The Lag Relationship between Producer and Consumer Prices: an Unobservable Variable Approach. Economics Letters 22: 175179. 